\title{
Economic Analysis of Irrigation Water under Different Water Use Regimes in Godavari Command Area
}

\author{
Banda Sainath ${ }^{1 *}$ and P.S. Srikantha Murthy ${ }^{2}$ \\ ${ }^{1}$ Research Scholar, Department of Agricultural Economics, ICAR-NDRI, Karnal, Haryana, India \\ ${ }^{2}$ Professor, Department of Agricultural Economics, UAS, GKVK, Bengaluru, India \\ *Corresponding author: sainathbanda1995@gmail.com (ORCID ID: 0000-0003-2427-3073)
}

Received: $13-02-2021$

Revised: 20-04-2021

Accepted: 29-05-2021

\begin{abstract}
A study was undertaken in Karimnagar and Warangal districts falling under the Godavari command area of Telangana to analyze the economics of irrigation among the farm households across surface water $(\mathrm{SW})$, groundwater $(\mathrm{GW})$ and conjunctive use $(\mathrm{CU})$ regimes. Data was analyzed using descriptive statistics and natural resource economics tools. The farms under CU realized higher net returns per acre (₹ 11792) followed by GW farms (₹ 8229) and SW farms (₹ 7516). There was also an enhanced savings to the extent of ₹ 10900 per acre due to reduction in the expenditure on human labour, machine labour, marketing and irrigation cost under CU regime when compared to GW regime. The per annum volume of surface water used in the case of SW farms and CU farms was 263 acre inches and 182 acre inches, respectively. Volume of water used in case of CU is less when compared to SW regimes. Annual cost of irrigation water per acre was found to be highest in GW farms (₹ 6916) when compared to SW (₹ 1284) and CU (₹ 4063) farms. This study has shown the potential benefits of CU regime over SW and GW regime.
\end{abstract}

\section{Highlights}

(0 This study focusses on quantification of water under three regimes of irrigation and also estimation of cost and returns of different crops cultivated in the command area.

Keywords: Conjunctive use, annual cost of irrigation, volume of water used, economics of irrigation

India is an agricultural economy where 80 to 85 per cent of the water is used for irrigation. It was estimated that about 40 per cent of the cultivated area is irrigated and among the irrigated area about 70 per cent is devoted to food crops to meet the needs of the ever-growing population (Badri, 2018). Thus, in tropical countries like India, irrigation plays a vital role in securing food for the masses. As the supply of land is highly inelastic and the net sown area growth is impossible and this has led to the dependence of agricultural productivity on efficient use of water and land resources. Irrigation has also greatly facilitated to diversify the cropping pattern towards high-value crops. Irrigation not only improved the food production and economic conditions of a large number of farmers but also contributed immensely towards ensuring food production and alleviating poverty. These benefits of the water through irrigation have increased the demand for water at an exploiting rate.

Water is usually treated as a 'public good' and has been over-exploited for years leading to its scarcity. In the command areas at the canals, farmers at the head reach areas over harvest the water from the canal due to its abundant availability. This led to the scarcity of water or less availability of this resource to the tail and mid reach farmers along the canal. This increase in the scarcity of water made the farmers to rely more on groundwater to irrigate the crops. As there is no assured source of

How to cite this article: Sainath, B. and Srikantha Murthy, P.S. (2021). Economic Analysis of Irrigation Water under Different Water Use Regimes in Godavari Command Area. Economic Affairs, 66(2): 305-310. Source of Support: None; Conflict of Interest: None $\infty$ 
surface water availability, farmers started digging a greater number of wells to exploit ground water without caring for its regeneration. Transaction costs have also become high for the tail end farmers due to free riding and illegal extraction of water which enhanced the guarding time of the tail reach farmers resulting in higher transaction cost (Ravi et al. 2019). Transaction cost includes information cost, contractual cost and enforcement cost as enunciated by Coase (1960).

While surface irrigation has been stagnating, groundwater irrigation has been increasing. Policies towards electricity, credit, technological innovations in well exploration, extraction and use, demographic shifts, lucrative product markets and weak groundwater institutions are contributing to overextraction. In the last four decades, groundwater extraction exhibited a trajectory of utilization, boom, growing scarcity and eventually bust with rapid fall in groundwater table in the hard-rock aquifers. This has forced several marginal and small farmers to shift to dry land agriculture.

To tackle this challenge of over-exploitation, a new method called conjunctive use of water was evolved where water from both the sources (surface and ground) are used. This method has the potential to offer economic and social outcomes with increased water use efficiency. Hence, this study was taken to estimate the cost of irrigation and economics of irrigation major crops under surface water (SW), Groundwater $(\mathrm{GW})$ and Conjunctive water (CU) use regimes.

\section{METHODS AND TOOLS}

\section{Data}

Godavari command area, falling under Karimnagar and Warangal districts of Telangana, was purposively selected as the study area. A random sampling technique was employed to select the farmer respondents, including 60 farmers dependent largely on Groundwater (GW), 60 farmers using Surface water (SW), and 60 farmers practicing Conjunctive Use of water (CU). The sample farmers were interviewed using the pre-tested and structured schedules to collect the required information. Secondary Data was collected from the Command Area Development Authority (CADA) regarding irrigation charges, cropping pattern, the area under command area, the storage capacity of the dam and so on.

\section{Tools}

\section{Quantification of water used by the crops}

\section{Surface water [SW]}

Quantity of
water used $=\begin{aligned} & \text { No. of Irrigations } \times \text { Depth } \\ & \text { of Irrigation }(\mathrm{cm}) \times \text { Area of } \\ & \text { Irrigation (ha) }\end{aligned}$

\section{Groundwater [GW]}

A volumetric water meter was used to calculate the yield of water from irrigation bore well.

Water yield
from BW $=\begin{aligned} & \text { Water discharge }(\mathrm{GPH}) \text { across } \\ & \text { all seasons } \times \text { No. of hours pump } \\ & \text { put on across all seasons }\end{aligned}$
22611

Note: One GPH=22611 acre-inches.

\section{Cost of Irrigation}

\section{Surface water}

The methodology and approach of Nagaraj et al (2002) was followed for valuing surface water or price of surface water in the present study. Authors estimated the price at ₹ 12 per acre inch during 2002. That price of canal water ( $₹$ 12/acre inch) was compounded at two per cent per annum to the present year and was worked out to be ₹ 16.47 per acre inch by 2018 and was used in the present study to valuate the surface water.

\section{Ground water}

Under variable cost component, variable cost of groundwater was estimated by amortizing investment on drilling and casing of bore wells over the economic life of bore well /s or subsistence life of bore well /s plus the maintenance and operation cost of the bore well. To obtain the fixed cost of ground water per acre inch. The amortized value of the fixed investment was divided by the total volume of extracted groundwater in the study year (2018).

$\begin{array}{ll}\text { Amortized } & \begin{array}{l}\text { Amortized cost of [borewell + pump set } \\ + \text { conveyance }+ \text { over ground structure }+\end{array} \\ \text { cost of } & =\begin{array}{l}\text { micro irrigation structure (mis)] }+ \text { annual } \\ \text { irrigation } \\ \text { repairs and maintenance cost of pump set } \\ \text { and accessories }\end{array}\end{array}$




\section{Other costs}

And other costs which vary with the level of production such as labor cost, cost of inputs, marketing costs and interest on working capital etc., were calculated and under fixed costs, rental value of land, depreciation, interest on fixed capital and land revenue and taxes were considered.

\section{Production function analysis}

The following form of Linear Dummy Variable Regression Model was employed to know the contribution of different irrigation regimes to the farm's net returns.

$$
Y=\beta_{0}+\beta_{1} X+\beta_{2} D_{1}+\beta_{3} D_{2}+\beta_{4} D_{1} X+\beta_{5} D_{2} X
$$

Where, Y-represents net returns (₹/farm); $X$-represents water used in acre-inches; $D_{1}$-represents dummy for groundwater irrigation; $D_{2}$-represents dummy for conjunctive use; $D_{1} X$ and $D_{2} X$-represent slope dummies which explicitly measure marginal productivity of groundwater due to groundwater irrigation and conjunctive use, respectively.

$\beta_{0^{\prime}} \beta_{1^{\prime}} \beta_{2^{\prime}} \beta_{3^{\prime}} \beta_{4^{\prime}} \beta_{5}$ are the regression coefficients.

\section{RESULTS AND DISCUSSION}

\section{Volumetric pricing of irrigation water in three different regimes}

The information on the cost of groundwater in the study area is required to make economic analysis of different crops. Hence, results on prices of irrigation water were estimated on volumetric basis and results are presented in Table 1 . It can be observed from the table that the per annum volume of surface water used in the case of SW farms and CU farms was 263 acre inches and 182 acre inches, respectively. Volume of water used in case of CU is less when compared to SW regimes as sufficient surface water would not be available and CU farmers also depend on ground water for irrigation. Using the procedure adopted by Nagaraj, et al. (2002), the cost of canal water using the imputed value of ₹ 16.47 / acre inch, worked out to be ₹ 4337/farm in the case of SW regime and ₹ 2994/farm in the case of CU regime. Similarly, the per farm per annum volume of GW used in GW regime and CU regime was 111 acre inches and 56 acre inches, respectively.

Based on the size of land holding and per acre inch cost of groundwater, the per farm per annum cost of ground water irrigation in the case of GW farms and CU farms stood at ₹ 34186 and ₹ 16864, respectively. The annual cost of irrigation water per acre was found to be ₹ 1284, ₹ 6916 and ₹ 4063, in SW, GW and CU regimes respectively (Table 1).

The Table 1 results show that volume of water used by SW regime is higher and cost of irrigation is less compared to that in other regimes, leading to over use of water by the farmers.

\section{Marginal Productivity of irrigation water under three regimes}

The Linear Dummy Variable Regression Model as given in methodology was employed to assess the contribution of different irrigation regimes to the farms' net returns. The dependent variable (net returns) was regressed with quantity of water used, two dummy variables viz., first one for conjunctive and another for ground water use, with slope dummy for CU and GW of water as independent variables. The results are presented in Table 2.

Table 1: Volumetric pricing of irrigation water in three different water use regimes

\begin{tabular}{|c|c|c|c|c|c|}
\hline Sl. No. & Particulars & Units & SW & GW & CU \\
\hline 1 & Farm size & Acres & 3 & 5 & 4 \\
\hline 2 & Volume of surface water used & Acre-inches & 263 & 0 & 182 \\
\hline 3 & Price of surface water considering the scarcity value & ₹/acre inch & 16.47 & 0 & 16.47 \\
\hline 4 & Cost of canal water per farm & $₹$ & 4337 & 0 & 2994 \\
\hline 5 & Volume of groundwater used & Acre-inches & 0 & 111 & 56 \\
\hline 6 & Average price of groundwater & ₹/acre inch & 0 & 309 & 248 \\
\hline 7 & Cost of groundwater per farm & $₹$ & 0 & 34186 & 13870 \\
\hline 8 & Total water used & Acre-inches & 263 & 111 & 238 \\
\hline 9 & Cost of irrigation water per farm & $₹$ & 4337 & 34186 & 16864 \\
\hline 10 & Annual cost of irrigation per acre & $₹$ & 1284 & 6916 & 4063 \\
\hline
\end{tabular}


Table 2: Marginal productivity of irrigation across different irrigation regimes $(n=180)$

\begin{tabular}{llll}
\hline S1. No. & Variables & Coefficients & t-stat \\
\hline 1 & R square & 0.75 & \\
2 & Adj. R square & 0.69 & \\
3 & Intercept & 5432.65 & 0.15 \\
4 & Water used in acre-inches $(\mathrm{X} 1)$ & $106.44^{*}$ & 11.51 \\
5 & Intercept dummy for Conjunctive use $\left(\mathrm{D}_{1^{\prime}}, 10\right)$ & $20713.59^{*}$ & 4.24 \\
6 & Intercept dummy for Ground Water use $\left(\mathrm{D}_{2^{\prime}}, 10\right)$ & 13244.01 & 0.90 \\
8 & Slope dummy for Conjunctive use $\left(\mathrm{D}_{1} \mathrm{X}\right)$ & 174.29 & 1.16 \\
9 & Slope dummy for Groundwater use $\left(\mathrm{D}_{2} \mathrm{X}\right)$ & $71.39^{*}$ & 5.82 \\
\hline
\end{tabular}

Note: ${ }^{*}$ indicates significant at 5 per cent probability level.

The estimated net returns (₹/farm/year) for SW, GW and CU regimes using the estimates of regression model are as follows.

1. $N R_{S W}=5432.56+\left(106.44^{*} 232.81\right)=₹ 24776.3$

2. $N R_{C U}=5432.56+\left(69.03^{*} 106.44\right)+20713.59+$ $\left(174.29^{*} 106.44\right)=₹ 46614.15$

3. $N R_{G W}=5432.56+\left(87.83^{*} 106.44\right)+13244.01+$ $(71.39 * 106.44)=₹ 30191.91$

Where, $N R=$ Net returns $(₹)$ and subscripts SW, GW and CU indicate Surface water, Groundwater and Conjunctive water regimes, respectively.

As mentioned earlier, per farm annual net returns were regressed against quantity of water used from different sources by the farm in the entire year. The intercept dummy coefficient captures the influence of technology on net returns realized.

It could be observed from the Table 2 that water used under CU regime would shift the net returns up by ₹ 20713.60 per farm, while GW regime shifts the net returns up by ₹ 13244.01 per farm. The marginal productivity of SW was found to be ₹ 106.44 per acre-inch, while that under GW regime was ₹ 71.39 per acre-inch and an acre inch of water under CU would add additional returns of ₹ 174.29 per acre-inch (Table 2).

The estimated regression function indicated that the bench mark net return of ₹ 24776.3 per farm represents the returns to surface water irrigation where groundwater and conjunctive use are not followed. The net returns per farm due to conjunctive use and groundwater use were ₹ 46614.15 and $₹ 30191.91$ respectively and are economically substantial, which is one of the main objectives of the present study of estimating the economic returns to technology of conjunctive use of water (Table 2).
The Table 2 results are in conformity with those reported by Priyanka (2009), Anand (2012), Suhas Chandra (2017).

\section{Cost and returns of principal crops under different irrigation regimes}

\section{Surface water}

Paddy which is a water-intensive crop was the only crop grown under surface water and it is also the staple crop of Telangana region. Volume of water used per acre was found to be 77.93 acreinches. Total cost of cultivation was estimated to be ₹ 33042 per acre, out of which total fixed costs was around ₹ 10570 (32\%) and total variable cost ₹ 22472 (68 \%). Due to highly subsidised water rates in case of surface water irrigation, irrigation cost was estimated to be ₹ 1284 per acre. Gross returns were estimated to be ₹ 40558 with an average yield of 24 quintals per acre. The percentage difference between net returns with irrigation cost and without irrigation cost was found to be 17 per cent.

To know the contribution of irrigation water to the net returns, net returns per rupee of irrigation cost was calculated which stood at ₹ 5.85. This implies that, every one rupee of expenditure incurred on irrigation would yield a net return of ₹ 5.85 (Table $3)$.

\section{Conjunctive water use}

In case of CU regime, share of irrigation cost in the total cost of cultivation was in the range of 7 per cent (cotton) to 13 per cent (maize). Volume of water used was highest in maize crop (24 acre-inches) followed by paddy (23 acre-inches) and cotton (18 acre-inches). The share of variable cost in total 
Table 3: Cost and returns of principal crops under surface water regime in Godavari command area (₹/acre)

\begin{tabular}{|c|c|c|c|c|c|c|c|c|c|c|c|c|c|c|}
\hline $\begin{array}{l}\text { Sl. } \\
\text { No. }\end{array}$ & Crop & $\mathbf{n}$ & $\begin{array}{l}\text { WU } \\
\text { (acre } \\
\text { inches) }\end{array}$ & $\begin{array}{l}\text { IC } \\
\text { (₹) }\end{array}$ & $\begin{array}{l}\text { TVC } \\
\text { (₹) }\end{array}$ & $\begin{array}{l}\text { TFC } \\
\text { (₹) }\end{array}$ & $\begin{array}{l}\text { TC } \\
\text { (₹) }\end{array}$ & $\begin{array}{l}\text { Yield } \\
\text { (q.) }\end{array}$ & $\begin{array}{l}\text { GR } \\
\text { (₹) }\end{array}$ & $\begin{array}{l}\text { NR } \\
\text { with } \\
\text { IC (₹) }\end{array}$ & $\begin{array}{l}\text { NR } \\
\text { without } \\
\text { IC (₹) }\end{array}$ & $\begin{array}{l}\text { Percentage } \\
\text { change in } \\
\text { NR with \& } \\
\text { without IC }\end{array}$ & $\begin{array}{l}\text { Returns } \\
\text { Per ₹ } \\
\text { of VC } \\
\text { (₹) }\end{array}$ & $\begin{array}{l}\text { Net } \\
\text { Returns } \\
\text { Per ₹ } \\
\text { of IC (₹) }\end{array}$ \\
\hline 1 & Paddy & 60 & 77.93 & 1284 & $22472(68)$ & $10570(32)$ & 33042 & 24 & 40558 & 7516 & 8799 & 17 & 1.80 & 5.85 \\
\hline
\end{tabular}

Table 4: Cost and returns of principal crops under conjunctive water regime in Godavari command area (₹/acre)

\begin{tabular}{|c|c|c|c|c|c|c|c|c|c|c|c|c|c|c|}
\hline $\begin{array}{l}\text { Sl. } \\
\text { No. }\end{array}$ & Crop & $\mathbf{n}$ & $\begin{array}{l}\text { WU } \\
\text { (acre } \\
\text { inches) }\end{array}$ & $\begin{array}{l}\text { IC } \\
\text { (₹) }\end{array}$ & $\begin{array}{l}\text { TVC } \\
\text { (₹) }\end{array}$ & $\begin{array}{l}\text { TFC } \\
\text { (₹) }\end{array}$ & $\begin{array}{l}\text { TC } \\
\text { (₹) }\end{array}$ & $\begin{array}{l}\text { Yield } \\
\text { (q.) }\end{array}$ & $\begin{array}{l}\text { GR } \\
\text { (₹) }\end{array}$ & $\begin{array}{l}\text { NR } \\
\text { with } \\
\text { IC (₹) }\end{array}$ & $\begin{array}{l}\text { NR } \\
\text { without } \\
\text { IC (₹) }\end{array}$ & $\begin{array}{l}\text { Percentage } \\
\text { change in } \\
\text { NR with \& } \\
\text { without IC }\end{array}$ & $\begin{array}{l}\text { Returns } \\
\text { Per ₹ } \\
\text { of VC } \\
\text { (₹) }\end{array}$ & $\begin{array}{l}\text { Net } \\
\text { Returns } \\
\text { Per ₹ } \\
\text { of IC (₹) }\end{array}$ \\
\hline 1 & Paddy & 60 & 23 & 3464 & 19957(61) & 12997(39) & 32954 & 26 & 47136 & 14182 & 17647 & 24 & 2.36 & 4.09 \\
\hline 2 & Cotton & 3 & 18 & 2693 & $28877(71)$ & $11857(29)$ & 40734 & 11 & 51188 & 10453 & 13147 & 26 & 1.77 & 3.88 \\
\hline 3 & Maize & 6 & 24 & 3676 & $19214(66)$ & $9907(34)$ & 29121 & 29 & 39861 & 10740 & 14413 & 34 & 2.07 & 2.92 \\
\hline
\end{tabular}

Table 5: Cost and returns of principal crops under ground water regime in Godavari command area (₹/acre)

\begin{tabular}{|c|c|c|c|c|c|c|c|c|c|c|c|c|c|c|}
\hline $\begin{array}{l}\text { S1. } \\
\text { No. }\end{array}$ & Crop & $\mathbf{n}$ & $\begin{array}{l}\text { WU } \\
\text { (acre } \\
\text { inches) }\end{array}$ & $\begin{array}{l}\text { IC } \\
\text { (₹) }\end{array}$ & $\begin{array}{l}\text { TVC } \\
\text { (₹) }\end{array}$ & $\begin{array}{l}\text { TFC } \\
\text { (₹) }\end{array}$ & $\begin{array}{l}\mathrm{TC} \\
\text { (₹) }\end{array}$ & $\begin{array}{l}\text { Yield } \\
\text { (q.) }\end{array}$ & $\begin{array}{l}\text { GR } \\
\text { (₹) }\end{array}$ & $\begin{array}{l}\text { NR } \\
\text { with } \\
\text { IC (₹) }\end{array}$ & $\begin{array}{l}\text { NR } \\
\text { without } \\
\text { IC (₹) }\end{array}$ & $\begin{array}{l}\text { Percentage } \\
\text { change in } \\
\text { NR with \& } \\
\text { without IC }\end{array}$ & $\begin{array}{l}\text { Returns } \\
\text { Per ₹ } \\
\text { of VC } \\
\text { (₹) }\end{array}$ & $\begin{array}{l}\text { Net } \\
\text { Returns } \\
\text { Per ₹ } \\
\text { of IC (₹) }\end{array}$ \\
\hline 1 & Paddy & 48 & 27 & 8276 & $23089(61)$ & 14470(39) & 37559 & 27 & 45422 & 7863 & 16139 & 105 & 1.96 & 0.95 \\
\hline 2 & Cotton & 20 & 20 & 6191 & $26134(63)$ & $15277(37)$ & 41411 & 11 & 50501 & 9089 & 15280 & 68 & 1.93 & 1.47 \\
\hline 3 & Maize & 5 & 21 & 6376 & $28160(69)$ & $12809(31)$ & 40969 & 32 & 48704 & 7735 & 14111 & 82 & 1.73 & 1.21 \\
\hline
\end{tabular}

Note: IC-Irrigation cost, TVC-Total variable cost, TFC-Total fixed cost, TC-Total cost, GR-Gross returns, NR- Net returns.

cost was the highest in cotton $(71 \%)$ and lowest in paddy $(61 \%)$. There was not much variability in the share of the fixed cost to the total cost which varied between 29 (cotton) and 39 per cent (paddy). Returns per rupee of variable cost were estimated to be around ₹ 2.36 in paddy and ₹ 1.77 in cotton. Net returns per rupee of irrigation were highest in paddy (₹ 4.08) (Table 4).

\section{Ground water}

In case of GW regime, share of irrigation cost to the total cost of cultivation was in the range of 15 per cent (cotton) to 22 per cent (paddy). Amount of water used was highest in paddy crop (27 acreinches) followed by maize (21 acre-inches) and cotton (20 acre-inches). The share of variable cost in total cost was the highest in maize $(69 \%)$ and lowest in paddy $(61 \%)$. There was not much variability in the share of the fixed cost to the total cost which varied between 31 (maize) and 39 per cent (paddy). Returns per rupee of variable cost were estimated to around ₹ 1.96 in paddy to ₹ 1.73 in maize. Net returns per rupee of irrigation was the highest in cotton (1.47) and the lowest in paddy (0.95) (Table 5).

\section{ACKNOWLEDGEMENTS}

I would like to thank all the farmers and officials of Command Area Development Authority (CADA) who spared their valuable time in providing the information and to ICAR-IIWM, Bhubaneshwar for providing financial support to undertake the study.

\section{CONCLUSION}

The scientific pricing of water shows the underpricing or under estimation of water cost in surface water regimes when compared to this study on Economic analysis of different water use regimes in Godavari command area. So, this study can be used as a reference to relook upon the pricing of water based on volume of water used in case of surface water regime and revise water rates in the command area. Other results have shown the superiority of conjunctive use over other two regimes. 


\section{REFERENCES}

Anand Plappally, K. and John Lienhard, H.V. 2012. Costs for Water Supply, Treatment, End-Use and Reclamation, Desalination and Water Treatment. Desalination and Water Treatment, 51(1/3): 200.

Chaterjee, B. 2018. Groundwater depletion owing to exceptionally high demand in India. Hindustan times, Bengaluru edition.

Coase, R.H. 1960. The Problem of Social Cost. J. Law and Econ., 3(1): 1-44.

Nagaraj, N., Shankar, K. and Chandrakanth, M.G. 2002. Pricing of Irrigation Water in Cauvery Basin. EPW., 5(2): 181-194.
Priyanka, C.N. 2009. Externalities in Groundwater Use on Drip and Conventional Irrigation Farms in the Eastern Dry zone of Karnataka. Thesis M Sc (Ag). University of Agricultural Sciences, Bengaluru, Karnataka, India.

Ravi, S.C., Umesh, K.B. and Srikantha Murthy. P.S. 2019. Transaction Cost in Irrigation Tank Management: An Institutional Economic Analysis. Eco. Affairs, 63(4): 785790.

Suhas Chandra, R.S. 2017. Institutional Economic Analysis of Conjunctive Use in Cauvery River Basin of Karnataka. Thesis M Sc (Ag). University of Agricultural Sciences, Bengaluru, Karnataka, India. 